\title{
Incommensurability and new economic strategies among indigenous and traditional peoples
}

\author{
Kathleen Lowrey ${ }^{1}$ \\ Department of Anthropology, University of Alberta, Canada
}

\section{Introduction}

Isoso is an indigenous community in tropical Bolivia. It comprises twenty-seven villages strung along one hundred kilometers of a seasonally-flooded river in lowland Bolivia's semi-arid Chaco. Nine thousand Guaraní speaking people, who call themselves "Isoseño", live in Isoso. Their agricultural technology is noteworthy for an elaborate system of irrigation that is maintained by cooperative labor and that dates to the pre-Columbian era. Primarily cultivators of maize, manioc, and (more recently) rice, Isoseño people supplement their diet with hunting and collecting in the dry tropical forest that extends for hundreds of kilometers to the east of their home territory. During the past century they have also earned cash income from seasonal migratory wage labor cutting sugar cane or harvesting cotton on regional plantations. At a distance of some three hundred and fifty kilometers from the nearest major city, linked in a sprawling chain of communities that lie far beyond the reach of asphalted roads, Isoseño people share a territory, an identity, and a hereditary leadership of several centuries' standing.

I carried out twenty months of ethnographic fieldwork in Isoso between 1997 and 2000, resulting in a series of anthropological publications. ${ }^{2}$ I have also returned to Isoso for shorter stays in the years since my original fieldwork. What I attempt to do in the present article is to consider the Isoseño experience through the lens of ecological economics and political ecology in order to complement these previous, more strictly anthropological, accounts. For this reason, I start in medias res and work back toward analysis.

One day early in 1999, administrative personnel from the Bolivian national park abutting Isoso arrived at the Isoseño village where I was then carrying out fieldwork. Their red Ford Explorer disgorged easels, flip charts, maps, aerial surveillance photos, trip-wire nighttime photographs of wild animals, and a troop of Isoseño, Bolivian, and foreign presenters. The visitors had arrived to explain and to obtain community approval for the park's official "management plan". Established in 1995 by presidential decree, the Kaa-Iya del Gran Chaco National Park ${ }^{3}$ is triply safeguarded by the enthusiastic support of Isoso's native leadership entity, the Captaincy of Upper and Lower Isoso (Spanish acronym, $\mathrm{CABI}$ ), the financial assistance of the United States Agency for International Development (USAID), and the scientific and technical expertise provided by conservation biologist advisors working for the Wildlife Conservation Society (WCS, the international conservation arm of the New York Zoological Society).

Although the Isoseño leadership had backed the establishment of the park in 1995 as part of a longterm strategy to buffer Isoso's territory from encroachment by ranchers and settlers, even by 1999 most people living in Isoso had only a vague idea of what the park was all about. The day's presentations were intended as a dialogue within narrow parameters. By the time this group of presenters rolled up to the village, the management plan was largely formulated, but they came to elicit and to document a representative measure of local input as required by Bolivian law. The first presenter was a Mexican biologist in the employ of WCS. Speaking in Spanish, she sketched pictures of dirty, smoggy faraway cities and described the pitiable contrast much of the outside world makes to the green and breathing local forest enjoyed by Isoseño people. The Isoseño audience, bilingual to variable degrees, was collectively nonplussed. When she finished, an Isoseño man employed by the park stood to reinforce her message - but not exactly to translate it. He began with an oratorical flourish: "our grandparents said this land was our storehouse, the source of our riches. And now we see with the park that it is."

\footnotetext{
1 Assistant Professor, Department of Anthropology, University of Alberta, Edmonton, Alberta T6G 2H4, Canada. Email: kathleen.lowrey "at" ualberta.ca.

${ }^{2}$ Lowrey, Kathleen. (2003) Enchanted ecology: magic, science, and nature in the Bolivian Chaco. Ph.D. dissertation, Department of Anthropology, University of Chicago; (2006a) "Bolivia multiétnico y pluricultural, ten years later: white separatism in the Bolivian lowlands" Latin American and Caribbean Ethnic Studies Journal 1(1): 63-84; (2006b) "Salamanca and the city: culture credits, nature credits, and the modern moral economy of indigenous Bolivia" Journal of the Royal Anthropological Institute 12(2): 272-295; Combés, Isabelle and Kathleen Lowrey. (2006) "Slaves without Masters? Arawakan dynasties among the Chiriguano (Bolivian Chaco, $18^{\text {th }}-20^{\text {th }}$ centuries)" Ethnohistory 53 (4): 689-714.

3 "Kaa-Iyaa" is a Guaraní word for "spiritual owner of the forest" - the kaa iyaa are guardian entities associated with forest animals and landscapes. The park's official name, then, implicitly acknowledges Guaraní guardianship and in the view of the Isoseño, effective ownership - of this national protected area.
} 
It is no surprise that an agent of the rich world would emphasize the green aspects of the park while an agent of the poor world would emphasize its potential to generate greenbacks (which is what the second speaker went on to do). However, as I considered the park in conjunction with another externally-funded enterprise underway in Isoso at the same time, I came to believe that this disjuncture pointed to something that would reward closer analysis. Specifically, the persistent interpellation of different kinds of "value" struck me as telling on anthropological, economic, and ecological grounds.

During the course of that same year (1999), I also bore witness to the meltdown of a traditional medicine project located in another Isoseño village. In 1996, the French and Bolivian governments funded the construction of a small, four-room "laboratory" next to the home of an Isoseño shaman. Enthusiastic French and Bolivian botanists and chemists set out to collaborate with knowledgeable Isoseño healers in order to identify, develop, and commercialize remedies derived from Isoseño medicinal plant lore. They were successful in the first two tasks, but not the third, and the project ended in a welter of recriminations about that failure. During one of the final visits by a French ethnobotanist to the shaman's household where I was living at the time, the shaman's wife pulled me aside to tell me she and her husband now felt sure that any plant samples the ethnobotanist took from the community were destined to be sold on the street in Bolivia's capital, La Paz, with the ethnobotanist and her urban colleagues pocketing the proceeds. While I was sympathetic to the sentiment, I knew this was not the case. For her part, the ethnobotanist and her colleagues became progressively more exasperated by what they came to see as the paranoid and grasping nature of their Isoseño erstwhile collaborators. While I was sympathetic to the sentiment, I also knew that this cynicism about "the Isoseño character" was misguided.

It would not be correct to say I was "caught" in the middle of these dynamics: in point of fact, I had effectively plopped myself into the midst of them, as often as not unbidden and unwelcome. Nevertheless, that ethnographic subject-position allowed me to make a simple-minded observation. In Isoso, neither the park nor the lab were assessed according to measures agreed upon by the groups of people who hoped - in different ways - for their success. But no-one involved in either project supposed them therefore to be worthless. So I began to wonder: what kinds of equivocal goods did they incarnate?

\section{Translation, mensuration, and globalization}

The notion of "incommensurability" has gained currency in the recent anthropological literature, lately marked by an article-length appraisal in the Annual Review of Anthropology. ${ }^{4}$ While measurement and calibration inhere in the term, anthropologists have in the main used it in a qualitative or metaphorical sense, to forward their disciplinary aim of more finely accounting for cultural and/or linguistic difference. At the same time, ecological economists like Joan Martinez-Alier are calling for their discipline to place "incommensurability of values at the centre of its analysis". ${ }^{5}$ This sudden mutuality of interest is intriguing. Why are such disparate disciplines running in analytic parallel, at least at the level of terminology? Their similar concerns seem to arise from their shared attention to globalization. This much maligned lexeme aptly captures the extension of the system par excellence of absolute commensurability - the capitalist market economy - and its effects on manifold cultural and natural worlds.

Reading the cultural anthropological and economic ecological literature together clarifies certain aspects of the Isoseño experience. Isoso is a community impacted by the market economy but still marginal to it. Isoseño people viewed the park and the lab projects with which they were involved during the late 1990s as (among other things) means of capturing globally commensurable value (money revenue) from the lumpy, uneven, incommensurable values most readily at their disposal: specifically, those of a unique ecosystem and a non-dominant culture.

From the perspective of non-Isoseño partners to these projects, both the co-managed park and the laboratory of traditional medicine were primarily oriented to non-economic values: the park to the preservation of pristine nature and the lab to the maintenance of traditional culture. To the extent they incorporated explicitly market-oriented dimensions (regulated cattle-ranching or eco-tourism in and around park territory, commercialization of local plant medicines) they did so in the service of these non-market goods. Nevertheless, discussion of monetary motivations and the relation of economic to non-economic orders of value exercised the passions of both Isoseño people and, ultimately, nonIsoseño outsiders involved in these projects.

\footnotetext{
4 Povinelli, Elizabeth. (2001) "Radical Worlds: The Anthropology of Incommensurability and Inconceivability." Annual Review of Anthropology 30 (1): 319-335.

${ }^{5}$ Martinez-Alier, Joan. (2002): pp. vii-viii. The environmentalism of the poor: a study of ecological conflicts and valuation. Cheltenham, UK: Edward Elgar.
} 


\section{The $L a b$}

The smaller of the two projects - the laboratory - was the infrastructural incarnation of a traditional medicine project designed to be an exemplar of "multicultural grassroots development" ${ }^{6}$ incorporating local and scientific knowledge for the benefit of an indigenous community. During the early 1990s, a team of Bolivian ethnobotanists collected samples of medicinal plants in Isoso with the assistance of Isoseño shamans. The Bolivian researchers on this project received financial and technical assistance from the French government to seek out useful plants that could be elaborated into simple, locally made, locally used, and locally sold treatments. Any eventual profits (in the end, none were ever generated) were to be re-invested in the project itself and in the Isoseño community. Among the plants taken from Isoso, they found one to be a robust fungicide. On the promise of this discovery, a barebones, four-room "laboratory" was built next to the home of a shaman in a remote Isoseño village. A Bolivian biochemist and a French ethnobotanist trained the Isoseño shaman and two younger Isoseño assistants in preparing an antifungal salve for eventual commercial sale. The project was exemplary of "hybridity" - the Isoseño traditionally used this plant as a food and sometimes in a tea, not topically synthesizing Western science and local knowledge. But it was not successful. The different hopes of the different participants for the project encompassed various goals: that the undertaking would provide a low-cost medication for local and regional markets, provide training and employment in Isoso, promote appreciation of traditional knowledge and of local biodiversity, and further a specifically Bolivian national scientific research and development agenda given an international context in which a poor country like Bolivia is usually unable to participate in "global science". ${ }^{7}$ By the time I began my fieldwork in 1998, the fortunes of the project were in decline. When I returned to the field for five more months of research in 2000, it had fallen apart. The laboratory is now used in a desultory fashion as a kind of shamanic clinic.

\section{The Park}

The park represents a more prepossessing achievement. The 3.44 million hectare Parque Nacional Kaa-Iya del Gran Chaco is the second largest national park in all of South America. It abuts Isoseño traditional territories, to which they have - unusually for a lowland South American indigenous group held collective title since the first half of the twentieth century (see Maps 1, 2). ${ }^{8}$ A 2002 internal evaluation offers a short history:

Since 1991, WCS (The Wildlife Conservation Society) and CABI have been collaborating on the design and implementation of a community-based wildlife management programme in the Bolivian Chaco based on WCS's extensive field research in Argentina, Paraguay and Bolivia. Chief among the key accomplishments of this collaboration has been the establishment, in September of 1995, of the Kaa-Iya del Gran Chaco National Park and Integrated Management Area (KINP). Covering some 3.4 million hectares, Kaa-Iya is the largest protected area in Bolivia, and contains the largest area of dry tropical forest under protection in the world. Following the establishment of the park, CABI was named coadministrator, under an agreement with the government of Bolivia. It is also the only protected area in the Americas established as a result of the initiative of a Native American People, and the only one where a Native American organization has primary administrative responsibilities. In 1995, USAID/Bolivia joined the partnership between WCS and CABI/FII, and began to provide resources to permit CABI/FII to address the diverse challenges that came with its new responsibilities as co-administrator of the KINP (Kaa Iya National Park). ${ }^{9}$

The Chaco is a dry tropical forest ecosystem, of a type highly imperiled around the world. ${ }^{10}$ The initial contact between CABI and WCS, which takes a special interest in dry forests, was established by an American wildlife biologist who had carried out research on endangered peccary populations in the Isoso region. In the early 1990s, Bolivian land reform favoring lowland peoples had not yet been

\footnotetext{
6 Healy, Kevin. (2001) Llamas, weavings, and organic chocolate: multicultural grassroots development in the Andes and Amazon of Bolivia. Notre Dame, Indiana: University of Notre Dame Press.

7 UMSA/CABI/ORSTOM. (1996). Perfil de proyecto: producción de la crema antifúngica "Aguaratimí" sobre la base de guirakillo planta medicinal de la etnia isoceña guaraní. La Paz, Bolivia: presented to DNCB/MDSMA.

8 Combés, Isabelle. (1996) Iyambae: historia de la Capitanía Izoceña. Santa Cruz de la Sierra, Bolivia: Capitanía del Alto y Bajo Isoso and Fundación Ivi Iyambae.

${ }^{9}$ Project Kaa-Iya. (2002) Project Evaluation. Santa Cruz, Bolivia.

10 Parker, Theodore A., Alwyn Gentry, Robin Foster, Louise Emmons, and J.V. Remsen, Jr. (1993) The lowland dry forests of Santa Cruz, Bolivia: a global conservation priority. Conservation International: Rapid Assessment Program Working Papers 4.
} 
implemented. Though CABI has since taken advantage of this reform, at the time of these initial contacts the park agreement appealed to the Isoseño leadership because it offered the community enormous leverage, funding, and leeway to deal with territorial encroachment. After the land reform, the park continued to be important to Isoseño people because it provided a significant number of salaried jobs.

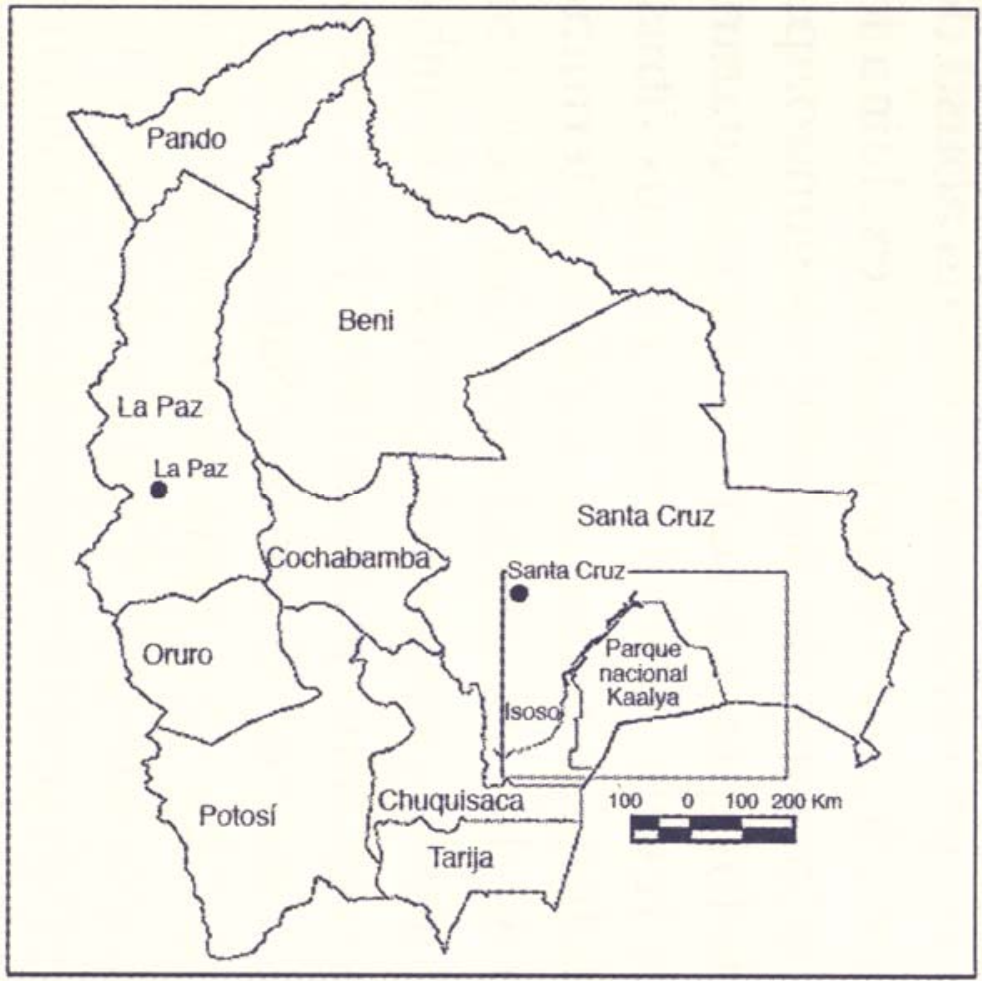

Map 1: Kaa-Iya National Park, Bolivia. Source: author.

Nonetheless, the Parque Nacional Kaa-Iya Gran Chaco exists apart from Isoseño, USAID, and WCS involvement, and will (theoretically) continue to be administered as a protected area by the Bolivian national park service whether or not any of the project members remain partnered with it. The park's enormous territory is crossed by a controversial natural gas pipeline, either abuts or includes portions of the territories of three unrelated indigenous groups (the Isoseño, the Chiquitano, and the Ayoreode), and in certain areas also abuts or includes land owned by agro-industrialists, large-scale ranchers, and ever-expanding colonies of traditionalist Mennonites. Isoseño leaders, however, tend to speak of the park as a straightforward extension of Isoseño territory, wholly under Isoseño control. In the community and out of it, the park employs close to one hundred people (by contrast, the traditional medicine laboratory never directly involved more than a dozen persons). ${ }^{11}$ Though few in number, these positions are the most prestigious jobs available to Isoseño people. They allow their holders to earn a wage that is far superior to local standards while living in Isoso, rather than out of it, and enable them to travel to the provincial town seat and departmental capital city to shop or seek medical treatment more or less at will. As of my last visit to Isoso in late 2005, the Proyecto Kaa-Iya was investigating productive options for replacing USAID funding (slated to phase out in 2006). People told me about prospects for bee-keeping, cattle-ranching, and a potential tourism venture, proposed in collaboration with various NGOs.

11 Something on the order of 200 Isoseño persons are employed by a "project," development, or other NGO (this includes the park). These are all extremely desirable positions because of the regular salaries, prestige, and often interesting kinds of work they involve: but employ a very small portion of Isoso's adult population (no more - and probably much less - than $10 \%)$. 


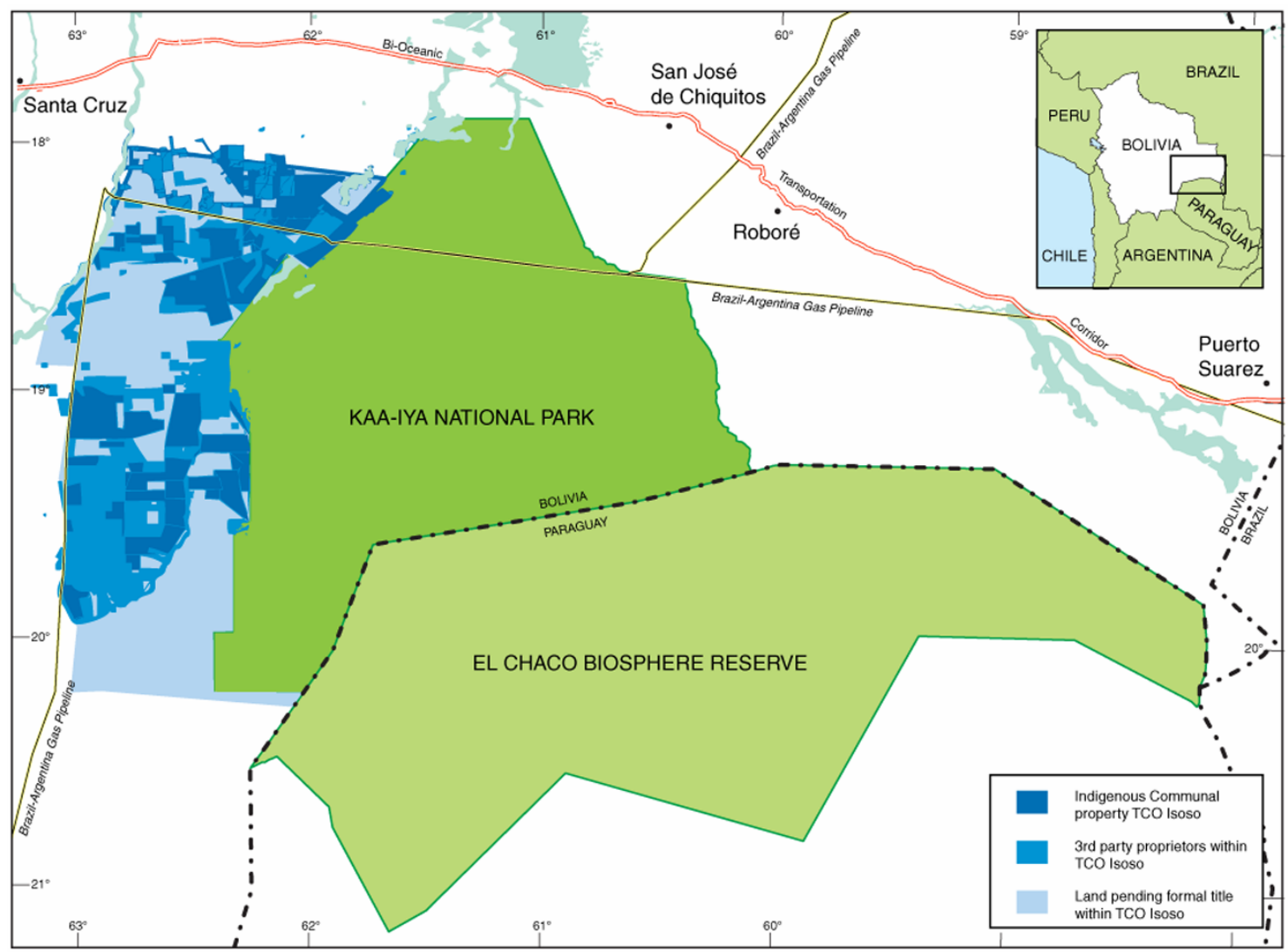

Map 2: Detailed map of Kaa-Iya National Park, neighboring indigenous territory and Biosphere Reserve, Bolivia. Source: Oliver Castillo, WCS, Santa Cruz, Bolivia. Revised with permission by UW-Madison Cartography Lab. In Naughton, L. (2007) Collaborative land use planning: zoning for conservation and development in Protected Areas. Tenure Brief 4. Madison WI: Land Tenure Center.

What I will argue in what follows is that these bootstrap models of self-sufficiency fundamentally misrecognize the political economic determinants of projects like the lab and the park. In the view of Isoseño people, the capture of outside revenue streams - and above all, straightforward aid funds - is a key capacity of such undertakings. The complement to this is that the outside partners to such undertakings are awkwardly implementing means for matching "nature" and "culture" with cash valuations. To explain this - to even suggest it - requires thinking in ways anthropologists usually resist; that is, in economic terms.

\section{Nature and the Park}

The larger of the two projects is best addressed first. In the 1990s, getting "indigenous and traditional peoples" involved in conserving their local ecosystems became something of an environmental policy-making fad. ${ }^{12}$ Inaugurated to little global or even national fanfare, the PN Kaa-Iya del Gran Chaco was designed as a quiet model for a newer generation of conservation efforts: involving local control, guided by scientific expertise, helped along by NGO inputs, respectful of national sovereignty but underpinned by foreign aid. ${ }^{13}$ Insofar as it is technocratically administered by an impoverished native people, the park contains, in itself, what ecological economist Joan Martinez-Alier has neatly delineated as the three main currents dominating contemporary global environmentalism: the

\footnotetext{
12 For a critical consideration, see Chapin, Mac. (2004) "A challenge to conservationists", World Watch Magazine November/December 2004.

13 The internal contradictions of this aspect of the Parque (national sovereignty/foreign aid) are important but will not form a focus of the present essay.
} 
Incommensurability and new economic strategies among indigenous and traditional peoples

cult of wilderness, the gospel of eco-efficiency, and the environmentalism of the poor. ${ }^{14}$

The cult of wilderness

In Martinez-Alier's view, the "cult of wilderness" aims:

...to preserve the remnants of pristine natural spaces outside the market. It arises from the love of beautiful landscapes and from deeply held values, not from material interests. Conservation biology, as it has developed since the 1960s, provides scientific support for this current of environmentalism. ${ }^{15}$

The park, with its dedicated contingent of WCS biologists, would seem to be a perfect manifestation of the "cult of wilderness". In the view of some conservation biologists, however, where it fails is in its involvement of local people in park management. John Terborgh is perhaps the best known skeptic regarding (indigenous and non-indigenous) poor people's commitment to environmental conservation. ${ }^{16}$ Terborgh advocates keeping parks in poor countries out of the hands of what he views as dubiously-qualified and dubiously-committed local residents. Instead, he'd like them heavily guarded and amply funded by national or, better, international agencies unbeholden to local interests. He pours scorn on the notion that indigenous and traditional peoples can be trusted as guarantors of the global environment.

Terborgh represents an emergent position: that of a hardnosed realist within what Martinez-Alier quite rightly has pegged as the fundamentally idealistic "cult of wilderness." These new realists are environmental advocates who have no time for misty romantic piffle about ecologically noble savages. But their brand of uncompromising "pragmatism" makes them extreme utopians. Given that ecological systems are imperiled (and even state and corporate behemoths concede they are) - but that public investment is a heavily politicized process - it is exceedingly naive to portray an approach that, as a first recourse, calls upon some of the most vulnerable global populations to do the hard work of salvaging ecosystems themselves as a plot sprung on the world by hippies (on behalf of everyone else, of course).

In the context of my field research, US\$3.4 million from USAID was a vastly impressive sum to Isoseño (and often repeated, shrunk and inflated by powers of ten: "thousands of dollars coming to Isoso! Can you imagine! Tens of millions of dollars coming to Isoso! Can you imagine!" Etc.). By the time it trickled down (through several communities abutting the park, through several layers of bureaucracy and technical assistance, and through the CABI leadership), it reached a fractious community of nine thousand people (working out, at a maximum, to US\$378/person: less, in fact, than the Isoseño average per capita income of US\$415 [in 1998]). ${ }^{17}$ Precisely because they are so poor, people in Isoso were immensely interested in the disposition of these meager funds. Through many a meeting, with many a four wheel drive sport utility vehicle jauntily speeding through the villages, after many a school educational program, and given many a rumor about the dimensions and power of the park proyecto, the community came to perceive their collective fate as tied to the Parque (as they already knew it to be to their ecosystem). This portion of the Chaco thus acquired a dedicated constituency and labor force (in the form of park guards, parabiologists, and support staff) on the cheap. Non-Isoseño partners to the project did not think of it in these terms, but Isoseño people certainly did.

\section{The gospel of eco-efficiency}

According to Martinez-Alier, the second major strand of contemporary environmentalism, the "gospel of eco-efficiency",

....is concerned about the whole economy... It believes in 'sustainable development', in 'ecological modernization', in the 'wise use' of resources.... Representatives of this second current scarcely use the word "Nature"; rather, they use 'natural resources' or even 'natural capital' or 'environmental services'. Disappearing birds, frogs, or butterflies 'bioindicate' that something is amiss... but they have not by themselves a self-evident right to exist. ${ }^{18}$

\footnotetext{
${ }^{14}$ Martinez-Alier op cit.

15 Ibid: 2

16 Terborgh, John (1996) Requiem for nature. Washington, D.C.: Island Press.

17 Annual income estimates for Isoso taken from Beneria-Surkin, Jordi. (1998) Socio-economic study of five Isoseño communities. Santa Cruz de la Sierra: Proyecto Kaa-Iya.

${ }^{18}$ Martinez-Alier op cit: 5.
} 
This, then, would seem to be a current of environmentalism in which unsentimental realists could burble and swim. And indeed, considerable energy goes into combining economic and conservation science models for protecting imperiled nature. ${ }^{19}$ A growing body of scholarship insists economic and ecological rationalities are eminently compatible. For example, a review article published in Science entitled "Economic reasons for conserving wild nature" concludes "the overall cost:benefit ratio of an effective global program for the conservation of remaining wild nature is at least 100:1." 20 Pragmatic environmentalists can similarly take heart from the news that even bad parks are better than no parks: another research article in Science compiles data from twenty-two nations to document the effectiveness of parks in protecting tropical biodiversity even under conditions of imperfect funding and staffing (though increased effectiveness correlates positively with both). ${ }^{21}$

Are only Western models - whether economic or ecological - "rational" in this sense? In fact, since the late 1970s many scientific studies have given indigenous peoples' cultural and environmental practices, too, a scientific imprimatur of legitimacy, for their efficacy, rationality, and sustainability in ecological terms. ${ }^{22}$ As Colchester and Gray have it,

...conservationists... are increasingly recognizing that indigenous peoples have access to refined technology and knowledge systems which include many sophisticated notions of conservation. $^{23}$

It is clear that ecologically thriving regions frequently coincide with the home territories of indigenous and traditional peoples. It would seem logically to follow that indigenous and traditional knowledge systems and ways of life might be harnessed to create efficient engines of conservation. Because anthropologists cannot help but applaud this long-overdue recognition of non-Western "ways of knowing", they have in the main been much more sympathetic to the "gospel of eco-efficiency" current of environmentalism than to the "cult of wilderness" one. Around the world, anthropologists have promoted syntheses of traditional and innovative ways to attach indigenous economic livelihoods to natural (and cultural) resources extant in the communities in which they work. My own attraction to Isoso as a field site was due in large part to the fact that the park initiative was so exemplary of this trend.

\section{The gospel of eco-efficiency and the cult of wilderness}

Combining the previous two strands, environmental economists are busy hatching methods of harnessing the values of wilderness to the ends of eco-efficiency. Their guiding principle is that if (for example) "Bolivia's national parks benefit not only Bolivians but people everywhere who might benefit from a medicinal compound, a scenic vista, or the knowledge that pink river dolphins have a home,"24 then this benefit is surely calculable in currency. Formulated this way, any environmental problem can be reduced to an intellectual struggle to calibrate "correct" prices in the absence of actual markets.

Contingent valuation (CV) studies seek to elicit from citizen-consumers, via a variety of increasingly sophisticated survey techniques, how much they might be willing to pay to preserve goods such as unspoiled vistas, spotted owls, and old growth forest, and/or how little they might accept in compensation to forego these goods if, for example, a toxic waste dump were built in their community and robbed them of clean air. Economists working on CV talk about "non-use values" and the

\footnotetext{
19 Almeida, Mauro and Manuela Carneiro da Cunha. (2000) "Indigenous people, traditional people, and conservation in the Amazon" Daedalus 129 (2): 315-338 do an admirable job of reviewing the history and present prospects of these trends.

${ }^{20}$ Balmford, Andrew, Aaron Bruner, Philip Cooper, Robert Costanza and Stephen Farber. (2002) "Economic reasons for conserving wild nature" Science 297: 950-953. One does wonder about methodologies that produce such resoundingly satisfying numbers; to an anthropologist, they smack of magical thinking.

21 Bruner, Aaron G., Raymond E. Gullison, Richard E. Rice, Gustavo A. B. da Fonseca. (2001) "Effectiveness of parks in protecting tropical biodiversity" Science 291: 125-128.

22 For overviews of this work see Redford, Kent and Christine Padoch (1992) Conservation of neotropical forests: working from traditional resource use. New York: Columbia University Press; Balèe, William (1994) Footprints of the forest: Ka'apor ethnobotany - the historical ecology of plant utilization by an Amazonian people New York: Columbia University Press; Descola, Philippe (1994) In the society of nature: a native ecology in Amazonia. Cambridge: Cambridge University Press; and Reed, Richard (1997) Forest dwellers, forest protectors: Indigenous models for international development Boston: Allyn and Bacon.

${ }^{23}$ Colchester, Marcus and Andrew Gray, eds. (1998): p. 12. From Principles to practice: indigenous peoples and biodiversity conservation in Latin America. Copenhagen: IWGIA Document \#87.

24 Steinberg, Paul (2001): p. 4. Environmental leadership in developing countries: transnational relations and biodiversity policy in Costa Rica and Bolivia. Cambridge: MIT Press.
} 
"existence value" of goods that are enjoyed but not exploited (let alone "produced") in a market-ready fashion. ${ }^{25}$ However, in spite of impressively honed techniques of elicitation, the elusiveness of good CV information points to a yawning gap of evaluative incommensurability. It has not escaped economists' notice that the frustrating process of getting reliable and consistent results from CV surveys suggests "something" is missing from the design of their studies, although their intuitions about what that might be are almost comically impoverished:

Economists... readily admit that direct elicitation of these values will require the skills of other social scientists, including survey research specialists, cognitive psychologists, political scientists, marketing specialists, sociologists, perhaps even philosophers. In fact, the critical scrutiny directed at the contingent valuation method has led some economists to think more deeply about cognitive processes, rationality, and the nature of preferences for all goods, public or private. 26

There is a sort of touching naiveté to this statement ("perhaps even philosophers"!) that offers a glimpse into an ingenuous discipline confronting epistemological problems regarding value and valuation (longtime obsessions, of course, of anthropology) of which it had hitherto functioned in happy ignorance. As James O'Connor wryly remarks upon such earnest yardsticking:

The whole issue of 'natural conditions' is becoming an increasingly important topic in economic theory today... the market treats external or natural conditions as fictitious commodities. With crackpot ingenuity, neoclassical economists today try to attach prices to clean air, attractive views, and other environmental amenities; wilderness reserves; even rainforests. ${ }^{27}$

Finally, as Elmar Altvater gently suggests, some problems with this method go beyond epistemological quibbles and right on to basic principles of ontology:

...much of the confusion in ecological economics circles over the appropriate "standard of value" or theory of price to adopt, stems from... failure to understand properly the radical gulf between the ecological logic of (irreversible) transformations and the economic logic of commutativity, equivalence-in-exchange, and equilibrium. ${ }^{28}$

Importantly, criticism of CV does not come only from the eco-socialist left. Hardline freemarketeers also deride the approach, because asking people about their values "is grossly impudent... To advocate 'existence valuation' protection at the expense of private property and contract rights is to advocate government by raw political power". ${ }^{29}$ Perhaps in response to this kind of dismissal of public (even if survey-driven) deliberation as "impudence", many otherwise progressive environmentalists have embraced CV as a potentially useful tool. In any event, this multilateral fractiousness over CV's attempt to generate a new universal standard of value mensuration is a significant recurrence of the issue of incommensurability. The point to note is that the debate raises issues proper to both ecological economics and anthropology. Finally, in the context of Isoso, there is yet a third aspect of environmentalism that must also be considered.

\footnotetext{
${ }^{25}$ Early reviews of this method include Levy, Daniel and David Friedman (1994) "The revenge of the redwoods? Reconsidering property rights and the economic allocation of natural resources" University of Chicago Law Review 493-526; Diamond, Peter and Jerry Hausman (1994) "Contingent valuation: is some number better than no number?" Journal of Economic Perspectives 8(4): 45-65; for a more recent review see Epstein, Richard (2003) "The regrettable necessity of contingent valuation" Journal of Cultural Values 27(3-4):259-274 (also available at http://culturalpolicy.uchicago.edu/CVMpapers/Epstein.html); and, for a ferocious critique of the CV method from a market-fundamentalist perspective, see Boudreaux, Donald, Roger Meiners and Todd Zywicki (1999) "Talk is cheap: the existence value fallacy" Environmental Law 29(4).

${ }^{26}$ Portney Paul (1994): p. 12-13. "The contingent valuation debate: why economics should care" Journal of Economic Perspectives 8(4): 3-18.

27 O'Connor, James (1998 Natural causes: essays in ecological marxism. New York: Guilford Press, 146-147

${ }^{28}$ Altvater, Elmar (1994) "Ecological and economic modalities of time and space" In Martin O'Connor, ed. Is capitalism sustainable? political economy and the politics of ecology. New York: Guilford Press, p. 90, footnote 10 .

29 Boudreaux et al op cit.
} 


\section{Environmentalism of the poor}

Martínez-Alier describes a third current of contemporary environmentalism, characterized:

...not [by] a sacred reverence for Nature but a material interest in the environment as a source and requirement for livelihood... Its ethics derive from a demand for contemporary social justice among humans. ${ }^{30}$

In the lived world of Isoso, community discussion of the park tended to focus not on the inherent value of "nature" but instead, very strongly on park-associated jobs: who got them, how the jobs changed their lives, whether more jobs might be created, and whether and how much park-associated funding was being personally siphoned off by community leaders. Outsiders involved in the park treated this evident fixation on filthy lucre with a sort of bemused cynicism that sometimes turned into near despair at the apparent refusal of Isoseño to appreciate the park on its non-economic, environmental merits. Isoseño, for their part, were apt to describe these same outsiders as feigning interest in nonmercenary themes and to suggest that, in truth, these outsiders were merely "using" Isoso and Isoseño people (given their demonstrated ability to attract funding as a culturally distinct, indigenous community in a relatively pristine ecosystem) as means to earn salaries.

Here, then, we see a point of agreement amongst actors whose worldviews might otherwise be described as less than perfectly commensurate: each set ascribed monetary avarice to the other. This is interesting, and opens up the heretofore elusive possibility of a comprehensive analysis. Elmar Altvater has pointed out:

Capitalist societies... not only provoke conflicts but they also make available the form in which they are handled: that is, the monetization of the ecological degradations of inner and outer human nature... [and] thus offers money not only as a way of solving economic and ecological problems but also as the medium of their ongoing management. ${ }^{31}$

Altvater's important insight returns us to the problematic with which we began. The late-capitalist system of economic cooperation among nation-states allows for opportunities - indeed, elicits such occasions - for economically marginal peoples in economically marginal nations to demand funding to protect "their" ecosystems (a move which drops both the problem and its solution into the laps of the relatively powerless). This happens not only with respect to "nature", but with respect to "culture", too.

\section{Culture and the Lab}

During the 1990s, a fleeting rush to prospect traditional knowledge (particularly plant knowledge) for promising medicines burgeoned and then dwindled when marketable-product-ready precursors from the forest proved elusive. ${ }^{32}$ Ferocious critics of this so-called "bioprospecting" or "biopiracy" were legion. A virtual cottage industry sprang up in cyberspace (and at indigenous congresses) denouncing the specter of biopiracy supposedly haunting traditional and indigenous communities. ${ }^{33}$ The immediate

\footnotetext{
30 ibid: 11.

${ }^{31}$ Altvater, Elmar (1993) The future of the market: an essay on the regulation of money and nature after the collapse of "actually existing socialism". London: Verso, 211-212.

32 As a typical example of the kinds of hyperbolic statements that circulated in this "rush" - and which have never been borne out - note the following, carefully couched without substantiation in the passive voice: "It has been estimated [how and by whom?] that by consulting indigenous peoples, bioprospectors can increase the success ration in trials from 1:100,000 samples to 1:2" in Kawell, JoAnn (2002) "Who owns knowledge?" NACLA Journal XXXV (5): 14-17. A genuine "value-added" benefit to the whole process of searching - from the perspective of pharmaceutical companies - was the ability to advertise that search: photo-narration of their much-vaunted research and development efforts (used to justify high prices at the consumption end of the pipeline) encompassed everything from earnest scientists in safety glasses searching for "new answers" in gleaming laboratories to swashbuckling ethnobotanists sitting at the feet of crinkly-eyed old shamans at the ends of the earth. This propaganda campaign spanned a natural-cultural continuum of exoticism from sexy high-tech chemistry to frondwaving primeval wisdom. However, since the yield of interesting compounds was effectively nil, and as the "press" associated with doing such research became overwhelmingly negative because of biopiracy protests, involved corporations have made for the exits post-haste (for detailed case-histories of specific such instances, see Hayden, Cori (2003) "From market to market: bioprospecting's idioms of inclusion." American Ethnologist 30 (3):359-371 and Greene, Shane (2004) "Indigenous People Incorporated? culture as politics, culture as property in contemporary bioprospection deals" Current Anthropology 45(2):211-237).

33 There is, of course, another arena in which accusations of biopiracy are not at all overblown. While ethnopharmaceutical research aiming to produce drugs from undiscovered medicinal plants has NOT produced
} 
impetus for these concerns (for they have a very deep historical basis) was the United Nations Convention on Biological Diversity, agreed to at the "Earth Summit" in Rio de Janeiro, Brazil, in 1992. Designed to foster exploration and benefit-sharing, a recent report concludes that in fact it has

...done little to quell poor nations' fears of exploitation. Nor has it yielded the expected bioprospecting bonanza. On the contrary, many pharmaceutical companies have withdrawn from the field for a variety of reasons, including doubts about its commercial benefits... the push for benefit-sharing by developing nations has given drug companies 'a negative image of bioprospecting... When risks outweigh the benefits, companies will do something else. ${ }^{34}$

The Bolivian scientists involved in designing the traditional medicine project in Isoso did so in conscious contrast to the "biopiratical" model. Nevertheless, a major cause of the collapse of the project was the entry of a Danish NGO into the community that was determined to cast as biopirates any outsiders in Isoso other than themselves. The aftermath was rather sad, because after the Isoseño ran off the project founders as a pack of potential if not actual thieves, the Danes lost interest and left as well. The suddenly bereft Isoseño began seeking out new outside partners to revive the old project. To date there have been no takers. Nevertheless, the traditional medicine project did manage to raise local consciousness about the manifold values of local nature (plant biodiversity in the form of traditional medicinal plants) and local culture (specifically, shamanic knowledge). Despite community controversy, on balance working with outsiders raised the prestige of several shamans at a time when shamanism has been under attack from growing numbers of evangelical Christian converts in the community. Therefore this project - a null entity in financial terms - produced some "goods" in spite of itself. A point elided in the discourse on biopiracy is that even corporate behemoths might smile on such an outcome.

How so? Too many critics of capitalism forget that at its worst, capital presupposes - and therefore needs - reservoirs of unexploited nature and independently, richly creative human culture (just as much as it does reserve armies of laborers). Of course, every other (non-capitalist) value system presupposes and therefore needs richly distinctive forms of nature and culture that exist outside the impoverished structures of resource management and competitive commodification, too. But it is important to understand that a world in which "nature" was reduced to tree farms and "culture" was reduced to American Idol would be as fatal to capitalism as it would be to hippies, hikers, long-haired intellectuals and traditional and indigenous peoples. Protecting nature and cultural diversity - as fonts of polymorphic value - are imperatives for capital as much as for alterglobalization ${ }^{35}$ activists. Capital would like to find ways to do this work either at a profit or at a minimum, socialized (that is, state-borne or marginal-populations-borne) cost. Alterglobalization activists would like to restructure the world system so such repair work becomes less necessary. In the abstract, however, everyone wants the same work done.

Again, as was the case with the park, outsiders associated with the traditional medicine project were disturbed by Isoseño "avarice". In the laboratory project in particular, the ethnobotanists and scientists involved became deeply frustrated by the ratcheting-up of Isoseño demands for compensation, in the context of a project that was not working well (or, in fact, at all). The laboratory was never properly up and running. There was a limited (by physical isolation, and endemic poverty) local demand for the medicines produced there. At present, to satisfy the small local demand, the shaman to whom the edifice effectively has been abandoned continues to make medicines on an ad-hoc basis. For him, the building is now a white elephant that he regards as a shame-making burden. It has become his lonely responsibility to look for ways to make use of the space and redeem the heady promise of the project's early days.

For their part, Isoseño also worried over the potentially boundless greed of outsiders. Were these outsiders stealing shamanic knowledge - a concrete gift, for which a lifetime of public service is due in return - and making money off of it in foreign metropolises? Were the plants they were gathering being sold, as Isoseño had heard, at great profit on the streets of the national capital, La Paz? Not all of this

profitable results in the modern era and there has been a retreat from research on that front, the pursuit of agriculturally-interesting plant genetic resources (and their supplanting by commercially produced, hybrid, or genetically modified varieties) continues unabated and rightfully remains a source of real concern and object of ongoing activism. See Kloppenburg, Jack (1988) First the seed: the political economy of plant biotechnology, 1492-2000. Cambridge: Cambridge University Press and Shiva, Vandana (1992) The violence of the Green Revolution: third world agriculture, ecology and politics. London: Zed Books.

34 Dalton, Rex 2004. "Natural resources: bioprospects less than golden" Nature 429: 598-600.

35 I use the term "alterglobalization" advisedly. The more usual "anti-globalization" is too easily caricatured as a kind of Luddism, when in fact what most critics of globalization as we know it seem to aspire toward is a different kind of world-wide connectedness rather than an abolishment of such connection. 
concern was prompted by the Danish NGO workers, though they certainly helped it along. Even if the transactions between the Isoseño and their French and Bolivian counterparts in these projects were "fair" in the limited terms of the interaction itself, there were obvious economic and historic inequalities between the well-heeled urban professionals arriving to this poor rural community and the community members who provided plants and knowledge to be carried off to distant destinations. Contestation over remuneration encapsulated a variety of social, political, and historical concerns. What can we make of this? Why were the bitterest battles always over money?

\section{Market values}

To answer that question, it is useful to notice that the park and the lab present perfectly complementary inversions of conventional economic valences. With the park, Isoseño people were suddenly able to earn an income from protecting - rather than exploiting - material nature in its existential presence. With the lab, Isoseño people attempted to earn income off exploiting - rather than existentially experiencing - traditional culture.

This particular pairing may be found in many places other than Isoso. The much ballyhooed "new economy" (or the so-called "post-materialist" economy, driven by meta-exploitation of "existence", information, knowledge, and culture) involves not just global financial centers, but populations and regions that were (and continue to be) marginal to the "old" economy. In fact, such populations and regions are particularly rich in these emergent sources of (hypothetical) value. Hypothetical because these forms of valuation are new, and therefore dependent upon legal and political frameworks that are still more in the form of scaffolding than in the form of fully established institutions. This unusual state of affairs makes visible the socio-political workings of economic valuation.

Here it becomes necessary to belabor the obvious, because it is so often overlooked. The centerpieces of the two projects - Isoseño cultural knowledge, on the one hand, and the Isoseño ecosystem, on the other, are not produced in fixed units by wage laborers. Isoseño culture and Isoseño nature are instead collective products of the cooperative labor of many generations of Isoseño people.

To understand why Isoseño people are so insistent this special kind of labor is eligible for cash compensation, it is important to go beyond the invocation of poverty and inequality. Philip McMichael has argued that because the "value regime of wage-labor" is now globally hegemonic, even non-wage forms of labor have become subject to its logic. ${ }^{36}$ Recall also Altvater's point that "Capitalist societies... not only provoke conflicts but they also make available the form in which they are handled"37 (the anthropologist must interject here that all societies do the same; vide the culture concept). This has real consequences for how people think about what kind of assemblage of entities makes up the world. I would suggest that - with respect to these outside projects - Isoseño have come to think of their nature and their culture, and their involvement in the production and reproduction of these entities, as "subject to the value regime of wage-labor": in other words, as forms of endeavor commensurable with money compensation. ${ }^{38}$ They realize very well that every member of the community participates in this work and, because they have locally created Isoso's nature and Isoso's culture over many generations, that there are "back wages" owed to them from the outset by the outside world interested in these goods. This also helps to explain the near-fury of community members at the paltry numbers of Isoseño people actually on the payrolls of either project.

Martinez-Alier rightly points out that "[p]oor people have a better chance of defending their interests in a non-economic terrain". ${ }^{39}$ Nevertheless, when outsiders come in and tell poor Isoseño that the local nature and the local culture that they have created are "valuable," it is almost inevitable that they will respond by thinking of pricing. After all, as CV studies and contestation over intellectual property rights at the cutting edge of contemporary economics demonstrate, it is not just Isoseño people's minds that are tracking along these lines. A key feature of globalization as we all know it is the assessment of nature and of culture according to the impoverished metrics of price.

\section{Indigenous monopolies}

Arturo Escobar has suggested that:

There is a reason why communities - particularly ethnic and peasant communities in the tropical rainforest areas of the world - are finally recognized as the owners of their

\footnotetext{
36 McMichael, Philip. (1999) "The global crisis of wage-labour" Studies in Political Economy 58: 11-40.

37 Altvater op cit.

38 This is not to say that Isoseño do not also have other frameworks for understanding and relating. Of course they do.

39 Martinez-Alier op cit.
} 
territories... but only to the extent that they accept seeing and treating territory and themselves as reservoirs of capital. ${ }^{40}$

It is noteworthy that Escobar uses the discomfiting expression "territory and themselves" (emphasis mine). Many scholars and commentators, highly sympathetic to the rights (individual and collective) of indigenous peoples, have bracketed some forms of cultural and intellectual property claims by these peoples as misguidedly essentialist. These bracketed sets of claims are supposed to be objectionable in that they apply to contingent socio-cultural formations. In this, they are treated separately from indigenous claims to territory, which are more "grounded" in that they pertain to a changeless material object (land). ${ }^{41}$ In other words, according to this scholarship, treating the traditional medicine and the park projects underway in Isoso similarly is a misunderstanding, and may even be a dangerous one.

But traditional cultural goods are more like natural goods than they are like proprietary software programs, or trade secrets for making soda pop. They create, in effect, conditions for monopolization in their very existence. Marx turned to this problem in Volume III of Capital:

...capital cannot create a waterfall from its own resources. The surplus profit that arises from the use of this waterfall thus arises not from the capital but rather from the use by capital of a monopolizable and monopolized natural force. Under these conditions, the surplus profit is transformed into ground-rent, i.e. it accrues to the owner of the waterfall... this rent is always a differential rent, for it does not contribute to determining the general production price of the commodity, but takes this as given... landed property does not create the portion of value that is transformed into surplus profit; rather it simply enables the landowner, the proprietor of the waterfall, to entice this surplus profit out of the manufacturer's pocket and into his own." ${ }^{42}$

Like waterfalls, goods like biodiversity and traditional culture are not found everywhere, nor are they replicable just anywhere. In effect, they introduce an irreducible unevenness to an otherwisetotalizing system. In other words, they exemplify incommensurability.

Does this matter now any more than it did when Marx chose to treat it toward the end of his magnum opus? Part six of volume III is, according to Ernest Mandel, "really all about... the more general problem of monopoly giving rise to surplus profit". ${ }^{43}$ Marx described the way monopoly "attracts" a portion of social surplus-value as rent. However, according to Baran and Sweezy, "like the classical economists before him, [Marx] treated monopolies not as essential elements of capitalism but rather as remnants of the feudal and mercantilist past". ${ }^{44}$ Later analysts within the Marxian tradition, however, have parted ways with Marx on this point.

Monopolies are not in fact anachronisms. In The fiscal crisis of the state, James O'Connor demonstrated that late capitalism suspends itself - like a trapeze artist swinging from handhold to handhold - from a string of successive monopolies over technical innovations that forestall crisis (automobiles, telecommunications, the internet, and the like). Because capitalism is inherently crisisdriven, the monopoly form becomes more, not less, important over time. ${ }^{45}$ In later work, O'Connor applies the same logic to ecological crisis. He pays minute attention to how capitalist development creates crises not only internally (that is, within the market economy - crises that are sequentially resolved by innovation and monopolies built around innovation) but externally (that is, outside market economy; in short, in the world itself). These repeated cycles of crisis/overcoming/expansion eventually

\footnotetext{
40 Escobar, Arturo (1998) "Constructing nature" In Alan Goodman and Thomas Leatherman, eds. Building a new biocultural synthesis: political-economic perspectives on human biology. Ann Arbor: University of Michigan Press, 57.

41 A highly cogent exemplar of this position may be found in Brown, Michael (1998) "Can culture be copyrighted?" Current Anthropology 39(2): 193-212.

42 Marx, Karl. (1981[1895]) Capital, Volume III. Translated by David Fernbach. New York: Vintage Books, 785786. In The great transformation (Boston: Beacon Press, 1944) Karl Polanyi made the most useful analysis of those goods that capital "cannot create... from its own resources", calling them (land and labor) "fictitious commodities". But anthropologists have largely failed to take note of the relevance of this (long-available) analysis for contemporary indigenous peoples.

43 Mandel, Ernest (1981). "Introduction" to Capital, Volume III. Translated by David Fernbach. New York: Vintage Books, 1981.

44 Baran, Paul and Paul Sweezy. (1968) Monopoly capital: an essay on the american economic and social order. Middlesex, England: Penguin Books, 18.

45 O'Connor, James. (1971) The fiscal crisis of the state. New York: St. Martin's Press.
} 
threaten the conditions of capitalism because they threaten the conditions of existence itself. ${ }^{46}$ The point is that capitalism does not aim at a despoiled environment nor a flattening-out of cultural and social richness. That these are outcomes of capitalist processes creates a problem (another variation on the theme of crisis) for the highly developed, late capitalist economy. The gloriously prolific global biosphere and the manifold array of human cultures are themselves precious reservoirs of both material medium, and generative innovation, for the contemporary market system.

While disagreeing on most fundamental points, in their condemnation of monopolies and rentierism, Marxian and neo-classical economists speak with one voice. "Rent-seeking" behavior is universally condemned: by the former as doubly unjust (representing the operation of an additional mechanism of exploitation within an already-exploitative system), by the latter as deforming free market competition. Modern anthropologists' segregation of cultural from territorial property rights falls right into line with conservative concern about "rent-seeking." Richard Posner warns that:

...intellectual property presents a more serious problem of what economists call "rentseeking" than physical property does. A "rent", in economics, is not a rental; it is an excess of revenue over cost. It is pure profit, which is to say profit in excess of the cost of capital. Rent seeking can be bad from a social standpoint because it can lead to excessive investment (emphasis mine).

But some monopolies are protective in a good sense. Some monopolies forestall crises everyone would like to avoid. And some rents from such monopolies are "enticed" from the pockets of the idle rich into those of the marginal poor. The proliferation of projects, funded by the wealthy world, oriented to protecting nature and culture, and tethered to particular indigenous and traditional communities, is an economic phenomenon as much as it is an anthropological or an ecological one.

\section{Conclusion}

The processes described here are well known to political ecologists, and symptomatic of market engulfment of all spheres of life: nature, culture, even identity. However, simultaneous to - and as much as - "marketization", these processes also indicate a committed struggle to temper market forces. Indigenous and traditional peoples' embrace of capitalist forms of valuation like market-oriented intellectual property and cultural property, or cooperation in environmental initiatives headed and funded by wealthy-nation actors, of course indicate the dominance of these global forms over local ones. Paradoxically, however, because they are meant to protect exceptions to the dominant rule, they are also testaments to the fact that alternate orders of value are not only possible, ${ }^{48}$ but that they already exist. The resilience of the monopoly form - that is, protective legislative frameworks that are at once amenable to the market yet remain partially outside of it - is particularly interesting in this respect. Ultimately, the Isoseño examples (and other similar instances - including native gaming in the United States, a monopoly on a service rather than a good), are market-oriented measures that depend on protectionist differentials. They might be defended on the grounds of "conserving nature"; of "promoting culture"; or in terms of righting historical injustice. What they share is that they facilitate the relentless marketization of everything existing while simultaneously undermining it: another example of "incommensuration".

Incommensurability is an immanent problem of "globalization". As such, it is perhaps not surprising that social scientists who otherwise might have little to say to one another are nowadays saying so much about the same thing. The experience of indigenous and traditional peoples, usually of interest only to anthropologists, is now at the cutting edge of economists' concerns. It doesn't matter to the Isoseño, of course, who are engaged in their own projects of world-making. Anthropologists and economists alike, however, might wish to take notice.

\footnotetext{
${ }^{46}$ O'Connor (1998) op cit.

47 Posner, Richard (2002) "The law and economics of intellectual property" Daedalus Spring: pp. 5-12.

${ }^{48}$ Here I am referencing the alter globalization slogan: "another world is possible".
} 


\begin{abstract}
:
This article takes as a central problem why both a tiny laboratory and an enormous national park were almost simultaneously established in a remote tropical Bolivian indigenous community (Isoso) in the mid-1990s. Both projects - laboratory and the park - were oriented to non-economic values: the laboratory to those of traditional medicine and culture and the park to those of unspoiled nature. However, Isoseño people were particularly attentive to the projects' economic value, exploring the ways these might act as wellsprings of money revenue. The analysis presented here suggests that the tension among divergent orders of value that characterizes the contemporary global situation can present special opportunities, and not just challenges, to indigenous and traditional peoples living in places like Isoso. The essay brings together discussions of "incommensurability" made separately in recent cultural anthropological and ecological economic literature in order to show how and why this is so.
\end{abstract}

Key words: indigenous peoples, economic strategies, traditional medicine, incommensurability, Bolivia, national park

\title{
Resumen:
}

Este trabajo se pregunta por qué, a mediados de la década de 1990, un pequeño laboratorio y un enorme parque nacional fueron establecidos simultáneamente en una remota comunidad indígena boliviana (Isoso). Ambos proyectos estaban orientados a la promoción de la cultura y la medicina tradicional, y el parque también procuraba mantener el medioambiente en un estado impoluto. Sin embargo, los isoseños se preocuparon particularmente por el valor económico de dichos proyectos, explorando las formas en que éstos podían servir como fuente de ingresos. El análisis propuesto sugiere que la tensión entre diferentes órdenes de valor que caracteriza a la situación global contemporánea puede proveer oportunidades especiales, y no sólo desafíos, a los pueblos indígenas que habitan regiones como el Isoso. El ensayo propone explicar el cómo y el por qué de este fenómeno combinando diversos planteos sobre el problema de la "inconmensurabilidad" que ofrece la actual literatura antropológica y ecológicoeconómica.

Palabras clave: comunidad indígena, estrategias económicas, la medicina tradicional, inconmensurabilidad, Bolivia, parque nacional

\section{Résumé:}

Cet article prend comme problème central une explication de l'établissement plus ou moins simultanée aux 1990s d'un petit laboratoire et un parc national énorme dans une petite communauté (Isoso) indigène et éloignée de la Bolivie. Les deux projets, le laboratoire et le parc, étaient orientés vers des valeurs non-économiques: la médicine et la culture traditionnelle ou la nature non-gâtée. Néanmoins, le peuple Isoseño était particulièrement empressé par les avantages économiques des projets, et ils cherchaient des moyens par lesquels ils pourraient devenir des sources de revenus monétaires. L'analyse présentée ici suggère que la tension parmi les valeurs divergentes caractérise la situation globale contemporaine et présente des opportunités, pas tout simplement des défis, aux peuples indigènes et traditionnelles qui habitent les endroits comme Isoso. L'essai réunit le discours sur l'incommensurabilité dans l'anthropologie culturelle récente et la littérature de l'écologie économique afin de montrer comment et pourquoi ceci est le cas.

Mots clef: peuples indigènes, stratégies économiques, la médicine traditionnelle, l'incommensurabilité, Bolivia, parc national 